\title{
PERANAN KOMPETENSI INTI DALAM MERGER DAN AKUISISI
}

\section{Dwi Sulistiani}

\begin{abstract}
Abstrak. Dalam era globalisasi dan pedagangan bebas dewasa ini strategi merger dan akuisisi merupakan fenomena yang semakin marak dilakukan oleh para pelaku bisnis dan semakin menarik untuk dicermati bersama. Untuk menjalankan perusahaan para manajemen perusahaan selalu dituntut menjaga pertumbuhan usahanya secara optimal. Penerapan strategi merger dan akuisisi merupakan jalan pintas untuk mewujudkan pertumbuhan usaha tanpa perusahaan perlu memulai dari awal suatu jenis usaha yang baru. Dalam suatu kondisi perusahaan yang kuat cenderung membeli perusahaan lain untuk meningkatkan daya saing dan penghematan biaya. Perusahaan yang terlibat dalam merger dan akuisisi akan dapat diperoleh pangsa pasar yang lebih besar dan efisiensi terhadap biaya. Perusahaan yang merasa tidak dapat bertahan hidup secara individual biasanya merelakan diri untuk menjadi target akuisisi. Merger dan akuisisi merupakan suatu realitas dan tantangan yang harus siap dihadapi oleh para pelaku usaha dalam era perdagangan bebas saat ini. Namun tingkat kesuksesan dalam melakukan kegiatan merger dan akuisisi juga sangat dipengaruhi oleh kondisi internal perusahaan meliputi sumber daya, kapabilitas dan kompetensi inti yang dimiliki oleh perusahaan. Tulisan ini akan mencoba memberikan pemahaman bahwa sumber daya, kapabilitas dan kompetensi inti merupakan faktor penting dalam melakukan kegiatan penggabungan usaha yang pada akhirnya dapat menentukan tingkat keberhasilan proses merger dan akuisisi yang sedang dijalankan oleh perusahaan.
\end{abstract}

Kata kunci : Sumber Daya, Kapabilitas, Kompetensi Inti, Diversifikasi, Merger dan Akuisisi

\section{PENDAHULUAN}

Peluang-peluang dan tantangan yang menarik berkaitan dengan diterapkannya ekonomi global. Amerika Serikat bukannya pasar tunggal terbesar didunia saat ini, pasar Eropa dengan 70 juta pelanggan potensial yang memiliki produk domestik bruto US\$ 8 trilyun merupakan pangsa pasar yang cukup besar yang siap untuk dikembangkan. Selain hal tersebut pada tahun 2015 total produk domestik bruto Cina diperkirakan akan lebih besar dari produk domestik bruto Jepang walaupun output perkapita masih lebih rendah (Hitt et al, 2001).

Ekonomi global adalah ekonomi dimana barang, jasa, orang-orang, keahlian dan gagasannya bergerak bebas lintas batas-batas geografis (Hitt et al,

Dwi Sulistiani, adalah Dosen Fakultas Ekonomi UIN Maulana Malik Ibrahim Malang 
2001). Daya saing sebuah perusahaan dicapai melalui akumulasi daya saing individu perusahaan dalam ekonomi global. Untuk mencapai hal ini maka sebuah perusahaan harus secara terus menerus meningkatkan daya saingnya dengan melihat dunia sebagai pasarnya.

Untuk meningkatkan daya saingnya perusahaan dapat melakukan strategi tingkat perusahaan. Strategi tingkat perusahaan adalah tindakan yang dilakukan untuk mendapatkan keunggulan kompetitif melalui pemilihan dan pengelolaan bauran bisnis yang bersaing dibeberapa industri atau pasar-pasar produk. Pendekatan utama terhadap strategi tingkat perusahaan adalah diversifikasi yang mengharuskan para manajemen perusahaan memiliki keahlian manajemen yang unik untuk dapat dipergunakan mengembangkan strategi multi bisnis dan meningkatkan daya saing strategis (Hitt et al, 2001). Trend diversifikasi ini sebagian timbul dkarenakan proses restrukturisasi melalui merger dan akuisisi.

Schweger, Csiszar \& Napier (1993) mengemukakan bahwa sejak tahn 1983 penggabungan usaha yang terjadi di Amerika setiap tahunnya mencapai angka 2500 lebih. Angka ini belum termasuk keterlibatan peruahaan Amerika dalam merger dan akuisisi antar negara yang jumlahnya juga meningkat drastis. Selain Amerika tren yang sama juga terjadi di Eropa, Asia dan wilayah negara lain. Di Cina misalnya antara tahun 1985-1996 terjadi merger dan akuisisi dengan nilai total nilai US \$ 5,3 milyar (Milman, 1999).

Peristiwa diatas diramalkan akan terulang kembali dimana menurut pakar strategi UBS Securities memperkirakan aktivitas merger dan akuisisi global akan semakin marak dan meningkat hinggal $15 \%$ dibanding tahun 2009 atau sekitar US\$ 2,5 triliun hingga US\$ 2,7 triliun nanti ditahun 2010. Ditambahkan pula bahwa alasan utama untuk melakukan aktivitas ini adalah banyaknya perusahaan menghasilkan arus dana (cash flow) yang signifikan. Pemulihan pertumbuhan ekonomi berarti perusahaan akan sering membeli pertumbuhan unorganic daripada perluasan bisnis secara organic (www.koran-jakarta.com, 2009). Informasi terkait yang memberikan dukungan pendapat tersebut antara lain dibulan September 2009 saham AS naik karena akuisisi perusahaan farmasi dan teknologi memberikan bukti bahwa merger dan akuisisi mulai meningkat kembali, Affiliated Computer Services Inc. melonjak $16 \%$ setelah Xerox Corporation membuat pembelian terbesar dengan menyetujui untuk membeli perusahaan tersebut dengan nilai US $\$ 6,4$ milyar. Abbot Laboratories naik 4,2\% karena rencana pembelian unit farmasi Solvay SA dan mengambil alih kontrol terhadap TriCor cholesterol drug. Cisco Systems Inc., naik 4\% setelah Barclays Plc memprediksi pendapatannya akan naik. (www.imf-x.com, 2009).

Demikian juga yang terjadi pada industri di dalam negeri, setelah serbuan bank-bank asing yang melakukan akuisisi terhadap bank-bank domestik akhirakhir ini juga terjadi pada perusahaan manufaktur. Setelah akuisisi Philip Morris mengambil alih saham PT HM Sampoerna Tbk dari pemilik lama ditahun 2005, terakhir British American Tobacco Plc (BAT) mengambil alih $85 \%$ saham dari PT Rajawali Corpora di bulan Juni 2009 (www.detikfinance.com, 2009) . Saat ini berkembang suatu pasar yang kegiatannya bukan berupa jual beli barang tetapi jual beli perusahaan (kepemilikan) dalam perusahaan. Pasar ini biasa disebut Market for Corporate Control (M.Ruki, 1997). 
Merger dan akuisisi ini banyak dilakukan karena tersedianya dan berkembangnya akses kepada sumber-sumber pembelanjaan perusahaan baik ekuitas maupun pinjaman jangka panjang. Dalam Payamta (2001) mengemukakan alasan dilakukannya aktivitas merger dan akuisisi antara lain 1). Economic of Scale, 2). Memperbaiki manajemen 3). Penghematan pajak. Tujuan merger dan akuisisi ini biasanya menyelamatkan perusahaan dari kebangkrutan untuk menghimpun kekuatan sehingga perusahaan pengakuisi menjadi lebih kuat dan mengurangi persaingan. Di Indonesia merger dan akuisisi ini dilakukan karena adanya faktor keuangan dan keinginan pemilik mengurangi beban kewajiban kepada pihak ketiga. Terlepas dari alasan-alasan dibalik aktivitas untuk melakukan merger dan akuisisi ini, hal yang penting adalah bagaimana strategi merger dan akuisisi ini dapat berhasil dengan baik. Bagaimanapun juga tingkat keberhasilan merger dan akuisisi yang dilakukan oleh perusahaan sangat dipengaruhi oleh baik maupun buruknya faktor internal yang dimiliki oleh perusahaan.

Tujuan penulisan makalah ini memberikan wawasan dan pemahaman bahwa bagaimana sumber daya, kapabilitas dan kompetensi inti yang dimiliki oleh perusahaan mempengaruhi tingkat keberhasilan strategi merger dan akuisisi yang dijalankan oleh perusahaan.

\section{TINJAUAN PUSTAKA}

\section{Sumber Daya, Kapabilitas dan Kompetensi Inti}

Sumber daya dapat diartikan bahwa input-input dalam proses produksi perusahaan. Peralatan modal, keahlian pegawai individual, hak paten, keuangan dan manajer yang berbakat dapat digolongkan sebagai sumber daya. (Hitt et al, 2001). Keunggulan kompetitif dapat diciptakan melalui kumpulan beberapa sumber daya yang unik. Sumber daya terbagi atas sumber daya berwujud yang meliputi keuangan, organisasi, fisik dan teknologi dan sumber daya tidak berwujud yang terdiri dari manusia, inovasi dan reputasi. Para pengambil keputusan ditantang untuk memahami sepenuhnya nilai strategis dari sumber daya berwujud dan tidak berwujud dimasing-masing perusahaannya. Nilai strategis dari sumber daya ditunjukkan oleh tingkat kontribusi yang dapat memberikannya kepada pengembangan kapabilitas, kompetensi inti yang pada akhirnya tercipta suatu keunggulan kompetitif.

Kapabilitas adalah kapasitas yang dimiliki perusahaan dengan memanfaatkan sumber daya yang ada dan diintegrasikan dengan tujuan yang telah ditetapkan perusahaan. Kapabilitas merupakan kemampuan perusahaan dalam menciptakan dan mengeksploitasi peluang-peluang eksternal dan mengembangkan keunggulan yang berdaya tahan ketika digunakan dengan wawasan dan keahlian (Hitt et al, 2001). Kapabilitas organisasi bukan merupakan "input" khusus seperti aset berwujud atau tidak berwujud, melainkan keahlian yang digunakan oleh suatu perusahaan untuk mengubah input menjadi output (Pearce \& Robinson, 2007). Sebagai contoh Dell Computer membangun pertumbuhannya selama 10 tahun pertama dengan menciptakan suatu organisasi yang mampu memproduksi dan mengirimkan PC yang dibuat khusus dan murah. Gateway dan Micon mencoba meniru Dell namun tetap tidak dapat mengejar kapabilitas organisasi Dell yang 
beragam. Dell kemudian merevolusi sistemnya dengan menggunakan internet untuk mengotomatisasi dan menyediakan layanan khusus sehingga menciptakan tingkat kapabilitas organisasional baru yang menggabungkan aset, tenaga kerja dan proses didalam organisasinya.

Kompetensi inti adalah sumber daya dan kapabilitas yang mejadi sumber keunggulan kompetitif bagi perusahaan melebihi para pesaingnya (Hitt et al, 2001) Kompetensi inti muncul setiap waktu melalui proses organisasi dalam mengakumulasi dan mempelajari bagaimana menggunakan sumber daya dan kapabilitas yang berbeda. Sebagai dasar untuk melakukan suatu tindakan kopetensi inti merupakan kumpulan aktivitas perusahaan yang dilakukan secara berbeda dibandingkan dengan perusahaan pesaing dan memiliki nilai yang unik atas barang dan jasa yang ditawarkan dalam periode yang lama. McKinsey \& Co merekomendasikan bahwa klien-klien mengidentifikasikan tiga atau empat kompetensi yang membentuk suatu tindakan strategis (Hitt et al, 2001). Kapabilitas ataupun sumber daya akan lebih bernilai jika sumber daya tersebut memiliki kriteria sebagai berikut (Pearce \& Robinson, 2007) :

1) Penting untuk dapat memenuhi suatu kebutuhan pelanggan secara lebih baik dibandingkan dengan alternatif lain,

2) Langka, hanya sedikit pihak lain yang memiliki sumber daya atau keahlian setingkat dengan yang dimiliki perusahaan,

3) Menghasilkan bagian terbesar dari laba keseluruhan dengan cara yang dikendalikan oleh perusahaan ,

4) Bersifat tahan lama atau berkesinambungan sejalan dengan waktu.

Dengan demikian kapabilitas strategis yang dikenal dengan kompetensi inti menjadi sumber keunggulan kompetitif bagi perusahaan dalam mengatasi para pesaingnya. Keunggulan kompetitif yang memiliki daya tahan dicapai ketika para pesaing telah berusaha dan tidak berhasil menduplikasi manfaat-manfaat dari strategi perusahaan atau ketika para pesaing kurang yakin dalam melakukan duplikasi tersebut. Dengan adanya kriteria kapabilitas yang bernilai, langka, terlalu mahal untuk ditiru dan tidak ada produk pengganti diharapkan perusahaan dalam mendesain produk dan jasanya secara konsisten memiliki kriteria tiga atau empat tersebut sehingga memiliki keunggulan kompetitif dibandingkan dengan para pesaingnya.

\section{Memilih Diversifikasi Untuk Membangun Nilai}

Sebagian besar perusahaan dimulai dengan satu unit usaha yang relatif kecil dengan melayani wilayah pemasaran yang relatif sempit. Pada mulanya perusahaan tersebut juga hanya menghasilkan ragam produk yang terbatas dan hanya didukung dengan permodalan yang tidak besar. Pada posisi ini biasanya perusahaan juga memiliki posisi penguasaan pasar yang relatif lemah dibandingkan dengan para pesaingnya. Oleh karena itu tidak heran jika pada mulanya diawali dengan usaha untuk bertahan hidup dan kemudian diikuti secara simultan dengan usaha mengembangkan perusahaan melalui pertumbuhan. Pada awal pertumbuhan biasanya bersifat konservatif dan difokuskan melalui pertumbuhan internal. Pengembangan usaha diarahkan sepenuhnya untuk meningkatkan volume penjualan, meningkatkan pangsa pasar dan menumbuh kembangkan loyalitas konsumen. 
Jika pada tahapan ini berhasil, perusahaan mencoba mengembangkan ragam produk yang dihasilkan dan memperluas jangkauan wilayah pemasaran dengan strategi pertumbuhan yang lebih agresif. Pada tahap ini perusahaan mulai memanfaatkan faktor eksternal dan melakukan diversifikasi usaha untuk menciptakan nilai perusahaan. Ketika perusahaan telah memilih strategi diversifikasi untuk memacu pertumbuhannya maka perusahaan harus mempertimbangkan strategi yang paling sesuai untuk terus mengembangkan nilainilai produknya. Perusahaan menggunakan strategi diversifikasi sebagai strategi tingkat perusahaannya dengan berbagai alasan. Kebanyakan perusahaan menerapkan strategi diversifikasi untuk meningkatkan daya saing strategis dari seluruh perusahaannya.

Perusahaan-perusahaan diversifikasi bervariasi menurut tingkatan diversifikasi diantara unit bisnisnya. Selain kategori-kategori bisnis tunggal dan bisnis dominan, perusahaan yang semakin terdiversifikasi diklasifikasikan menjadi kategori berkaitan dan tidak berkaitan (Hitt et al, 2001). Sebuah perusahaan berkaitan melalui diversifikasinya ketika terjalin hubungan diantara unit-unit bisnisnya. Semakin erat jalinan diantara unit-unit bisnisnya semakin dibatasi keterkaitan diversifikasinya. Ketidakberkaitan merujuk ketidak adanya hubungan langsung diantara unit bisnis-bisnisnya.

Sebuah perusahaan yang mengejar diversifikasi tingkat rendah memusatkan usahanya pada bisnis tunggal atau bisnis dominan. Sebuah perusahaan diklasifikasikan sebagai bisnis tunggal ketika pendapatan dihasilkan oleh bisnis dominannya lebih besar dari $95 \%$ total penjualannya. Bisnis dominan adalah perusahaan yang menghasilkan antara $70 \%$ sampai dengan $95 \%$ dari total penjualannya. Adapun perusahaan yang memiliki tingkat diversifikasi moderat hingga tinggi yaitu bilamana perusahaan memiliki volume penjualan sebuah perusahaan 30\% lebih dari bisnis dominannya dan ketika bisnis-bisnisnya saling berkaitan dengan satu sama lain dengan cara tertentu perusahaan ini diklasifikasikan sebagai perusahaan diversifikasi yang berkaitan (Hitt et al, 2001).

Dengan demikian dapat disimpulkan bahwa motivasi perusahaan melakukan strategi diversifikasi adalah strategi perusahaan yang bertujuan untuk membangun atau memperluas daya saing strategis, memperoleh insentif dan sumber daya dengan dampak netral terhadap daya saing strategis serta adanya motif manajerial (Hitt et al, 2001). Perusahaan yang memiliki diversifikasi berkaitan merupakan strategi tingkat perusahaan yang berusaha menggali jangkauan ekonomis diantara unit-unit bisnisnya. Jangkauan ekonomi dalam hal ini dapat diartikan penghematan biaya yang berkaitan dengan pentransferan kapabilitas dan kompetensi yang dikembangkan dalam satu bisnis ke sebuah bisnis yang baru dan hal ini dapat dilakukan melalui strategi merger dan akuisisi.

\section{Strategi Merger dan Akuisisi}

Merger dan akuisisi merupakan salah satu strategi diversifikasi perusahaan dalam rangka membangun nilai perusahaan dan memelihara pertumbuhannya secara optimal. Arti merger berasal dari kata "mergere" (Latin) yang berarti (1) bergabung bersama, menyatu, berkombinasi (2) menyebabkan hilangnya identitas karena terserap atau tertelan sesuatu. Merger didefinisikan sebagai penggabungan dua atau perusahaan yang kemudian hanya ada satu perusahaan yang tetap hidup 
sebagai badan hukum, sementara yang lainnya menghentikan aktivitasnya atau bubar (Moin, 2003). Definisi lain mengatakan merger adalah sebuah strategi dimana dua perusahaan setuju untuk menyatukan kegiatan operasionalnya dengan basis yang relatif seimbang karena mereka memiliki sumberdaya dan kapabilitas yang secara bersama-sama dapat menciptakan keunggulan kompetitif yang lebih kuat. (Hitt et al, 2001). Sementara akuisisi berasal dari kata acquisitio (Latin) dan acquisition (Inggris), makna sesungguhnya akuisisi adalah membeli atau mendapatkan sesuatu/obyek untuk ditambahkan pada sesuatu/obyek yang telah dimiliki sebelumnya. Akuisisi dalam teminologi bisnis diartikan sebagai pengambilalihan kepemilikan atau pengendalian atas saham atau aset suatu perusahaan oleh perusahaan lain, dan dalam peristiwa baik perusahaan pengambilalih atau yang diambil alih tetap eksis sebagai badan hukum yang terpisah (Moin,2003). Definisi lain mengatakan bahwa akuisisi adalah strategi yang melaluinya suatu perusahaan membeli hak untuk mengontrol atau 100 persen kepemilikan terhadap perusahaan lain dengan tujuan untuk menggunakan kompetensi inti perusahaan itu secara efektif dengan cara menjadikan perusahaan yang diakuisisi itu sebagai bagian dari bisnis dalam portofolio perusahaan yang mengakuisisi (Hitt et al, 2001). Pada umumnya strategi integrasi dan diversifikasi dilaksanakan dengan akuisisi (Muhammad, 2003). Sedangkan pengambil alihan (takeover) adalah salah satu tipe strategi akuisisi dimana perusahaan sasaran tidak menghendaki penawaran perusahaan yang mengakuisisi (Hitt et al, 2001).

Pada prinsipnya terdapat dua motif yang mendorong sebuah perusahaan melakukan merger dan akuisisi yaitu motif ekonomi dan motif non-ekonomi. Motif ekonomi berkaitan dengan esensi tujuan perusahaan yaitu meningkatkan nilai perusahaan atau memaksimumkan kemakmuran pemegang saham. Di sisi lain, motif non ekonomi adalah motif yang bukan didasarkan pada esensi tujuan perusahaan tersebut, tetapi didasarkan pada keinginan subyektif atau ambisi pribadi pemilik atau manajemen perusahaan (Moin, 2003). Adapun beberapa motif dalam melakukan merger dan akuisisi dapat disampaikan sebagai berikut :

1) Motif Ekonomi

Esensi tujuan perusahaan dalam perspektif manajemen keuangan adalah seberapa besar perusahaan mampu menciptakan nilai (value creation) bagi perusahaan dan bagi pemegang saham. Merger dan akuisisi memiliki motif ekonomi yang tujuan jangka panjangnya adalah untuk mencapai peningkatan nilai tersebut. Oleh karena itu seluruh aktivitas dan pengambilan keputusan harus diarahkan untuk mencapai tujuan ini. Motif strategis juga termasuk motif ekonomi ketika aktivitas merger dan akuisisi dilakukan untuk mencapai posisi strategis perusahaan agar memberikan keunggulan kompetitif bagi perusahaan. Biasanya perusahaan melakukan merger dan akuisisi untuk mendapatkan economies of scale dan economies of scope.

2) Motif Sinergi

Salah satu motivasi atau alasan utama perusahaan melakukan merger dan akuisisi adalah menciptakan sinergi. Sinergi merupakan nilai keseluruhan perusahaan setelah merger dan akuisisi yang lebih besar dari pada penjumlahan nilai masing-masing perusahaan sebelum merger dan akuisisi. Sinergi dihasilkan melalui kombinasi aktivitas secara simultan dari 
kekuatan atau lebih elemen-elemen perusahaan yang bergabung sedemikian rupa sehingga gabungan aktivitas tersebut menghasilkan efek yang lebih besar dibandingkan dengan penjumlahan aktivitas-aktivitas perusahaan jika mereka bekerja sendiri. Pengaruh sinergi bisa timbul dari empat sumber 1). Penghematan operasi, yang dihasilkan dari skala ekonomis dalam manajemen, pemasaran, produksi atau distribusi; 2). Penghematan keuangan, yang meliputi biaya transaksi yang lebih rendah dan evaluasi yang lebih baik oleh para analisis sekuritas; 3). Perbedaan efisiensi, yang berarti bahwa manajemen salah satu perusahaan, lebih efisien dan aktiva perusahaan yang lemah akan lebih produktif setelah merger dan 4). Peningkatan penguasaaan pasar akibat berkurangnya persaingan (Brigham et al, 2001).

3) Motif Diversifikasi

Diversifikasi adalah strategi pemberagaman bisnis yang bisa dilakukan melalui merger dan akuisisi. Diversifikasi dimaksud untuk mendukung aktivitas bisnis dan operasi perusahaan untuk mengamankan posisi bersaing.

4) Motif Non Ekonomi

Aktivitas merger dan akuisisi terkadang dilakukan bukan untuk kepentingan ekonomi saja tetapi juga untuk kepentingan yang bersifat nonekonomi, seperti prestise dan ambisi. Motif non-ekonomi bisa berasal dari manajemen perusahaan atau pemilik perusahaan.

Diputuskannya merger dan akuisisi sebagai strategi pengembangan usahanya maka secara spesifik perusahaan memperoleh manfaat merger dan akuisisi (Moin, 2003) antara lain :

1) Mendapatkan cashflow dengan cepat karena produk dan pasar sudah jelas. Produk yang telah dikenal dan pasar yang jelas memudahkan perusahaan untuk memasarkan produknya.

2) Memperoleh kemudahan dana/pembiayaan karena kredititor lebih percaya dengan perusahaan yang telah berdiri dan mapan.

3) Memperoleh karyawan yang telah berpengalaman.

4) Mendapatkan pelanggan yang telah mapan tanpa harus merintis dari awal.

5) Memperoleh sistem operasional dan administratif yang mapan.

6) Mengurangi resiko kegagalan bisnis karena tidak harus mencari konsumen baru.

7) Menghemat waktu untuk memasuki untuk memasuki bisnis baru.

8) Memperoleh infrastruktur untuk mencapai pertumbuhan yang lebih cepat.

Disamping memiliki keunggulan, merger dan akuisisi juga memiliki kelemahan antara lain:

1) Proses integrasi yang tidak mudah.

2) Kesulitan menentukan nilai perusahaan target secara akurat.

3) Biaya konsultan yang mahal.

4) Meningkatnya kompleksitas birokrasi.

5) Biaya koordinasi yang mahal.

6) Seringkali menurunkan moral organisasi.

7) Tidak menjamin peningkatan nilai perusahaan.

8) Tidak menjamin peningkatan kemakmuran pemegang saham 


\section{PEMBAHASAN}

Merujuk dari pembahasan sebelumnya bahwa kompetensi inti merupakan sumber daya dan kapabilitas yang mejadi sumber keunggulan kompetitif bagi perusahaan melebihi para pesaingnya. Kompetensi inti muncul setiap waktu melalui proses organisasi dalam mengakumulasi dan mempelajari bagaimana menggunakan sumber daya dan kapabilitas yang berbeda. Sebagai dasar untuk melakukan suatu tindakan kopetensi inti merupakan kumpulan aktivitas perusahaan yang dilakukan secara berbeda dibandingkan dengan perusahaan pesaing dan memiliki nilai yang unik atas barang dan jasa yang ditawarkan dalam periode yang lama. Perusahaan yang melakukan penggabungan usaha mempertimbangkan kompetensi inti masing-masing perusahaan yang mendukung menghasilkan sumber daya dan kapabilitas yang komplementer sehingga meningkatkan daya saing dibandingkan dengan para pesaingnya. Berdasarkan riset yang dilakukan oleh Hussinger, (2005) menyimpulkan bahwa kompetensi inti mengendalikan aktivitas merger dan akuisisi. Selanjutnya dikatakan bahwa perusahaan cenderung memilih melakukan merger dan akuisisi dengan industri yang sejenis dan penerapan teknologi yang hampir sama.

Perusahaan menerapkan strategi diversifikasi untuk menggali jangkauan ekonomis diantara unit-unit bisnisnya. Jangkauan ekonomi dalam hal ini dapat diartikan penghematan biaya yang berkaitan dengan pentransferan kapabilitas dan kompetensi yang dikembangkan dalam satu bisnis ke sebuah bisnis yang baru. Peluang-peluang untuk membangun nilai melalui strategi diversifikasi, integrasi atau merger dan akuisisi banyak ditemukan dalam aktivitas-aktivitas yang berkaitan pertimbangan sumber daya, kapabilitas dan kompetensi inti masingmasing perusahaan. Merger dan akuisisi merupakan upaya melakukan sinergi diantara perusahaan yang akan melakukan penggabungan. Beberapa hal yang perlu dipertimbangkan dalam rangka upaya melakukan sinergi untuk meningkatkan kompetensi inti (Pearce \& Robinson, 2007) sebagai berikut :

1) Setiap kompetensi inti harus menyediakan suatu keunggulan kompetitf yang relevan bagi bisnis yang direncanakan.

2) Bisnis dalam portofolio harus berkaitan dengan cara-cara yang dapat membuat kompetensi inti perusahaan menguntungkan.

3) Kombinasi kompetensi apapun haruslah unik dan sulit untuk ditiru.

Keberhasilan atau kegagalan suatu merger dan akuisisi dapat dilihat pada saat proses sebelum bergabungnya perusahaan, selama dan sesudah penggabungan perusahaan. Pada saat proses ini biasanya terjadi sudut pandang yang berbeda-beda antara fungsi organisasi dalam menanggapi pengambilan keputusan merger dan akuisisi seiring dengan meningkatnya momentum, selanjutnya terjadi rancunya pengharapan dimana terjadi perbedaan-perbedaan harapan dipihak manajemen. Dari proses tersebut dapat memunculkan faktor-faktor yang yang memicu permasalahan merger dan akuisisi yang disebabkan karena kurangnya pertimbangan dan analisis yang mendalam terhadap kompetensi inti yang dimiliki oleh perusahaan (Hitt, et al, 2001) antara lain :

1) Kesulitan Integrasi 
Mengintegrasikan dua perusahaan yang melakukan merger dan akuisisi tidak mudah. Isu-isu integrasi meliputi meleburkan dua kebudayaan perusahaan yang berbeda, membangun relasi pekerjaan yang efektif dan memecahkan masalah berkaitan dengan status eksekutif perusahaan yang baru diakuisisi tersebut. Sebelum merger dan akuisisi terealisir karyawan dan para eksekutif (khususnya yang tidak melakukan negosiasi) yang akan digabung biasanya menghadapi apa yang disebut merger sindrome (Ashford, 1988, Mark \& Mirvis, 1997) dan ketidak cocokan organisasi apa yang disebut dengan alculturative stress (Very, Lubatkin \& Calory, 1996). Berdasarkan penelitian bahwa manusia dan budaya dapat menjadi variabel penghambat keberhasilan merger dan akuisisi dan hampir $50 \%$ tingkat kegagalan merger dan akuisisi disebabkan kedua variabel ini (Sobirin, 2001).

2) Evaluasi sasaran yang tidak memadai

Studi kelayakan adalah proses perusahaan mengevaluasi perusahaan sasaran untuk diakuisisi. Proses studi kelayakan yang efektif mempelajari ratusan hal dalam bidang-bidang yang beragam, perbedaan kultur antara perusahaan sasaran dan perusahaan yang mengakuisisi, konsekuensi pajak dari transaksi tersebut dan tindakan yang diperlukan untuk menggabungkan kedua perusahaan. Kegagalan melakukan proses studi kelayakan yang efektif seringkali membuat perusahaan yang melakukan akuisisi membayar dengan harga premium.

3) Hutang yang banyak dan luar biasa.

Faktor hutang dapat memiliki efek positif dan negatif. Hutang dapat menjadi penggerak positif bagi perkembangan perusahaan ketika dapat dimanfaatkan untuk mengisi peluang-peluang yang ada guna ekspansi perusahaan. Namun terlalu banyak hutang juga dapat memiliki efek negatif ketika hutang yang terlalu besar dapat mempengaruhi operasional perusahaan antara lain berakibat penundaan investasi yang dapat mempengaruhi terhadap daya saing perusahaan.

4) Ketidak mampuan sinergi.

Sebuah perusahaan yang mengembangkan keunggulan kompetitif melalui strategi merger dan akusisi hanya ketika suatu transaksi menghasilkan sinergi. Sinergi dapat tercipta ketika proses kombinasi dan integrasi dari aset perusahaan yang membeli dan dibeli ataupun dimerger menghasilkan kapabilitas dan kompetensi inti yang dapat dikembangkan dengan mengkombinasikan dan menyatukan aset perusahaan dengan milik perusahaan lain. Sinergi dapat dilakukan ketika aset perusahaan saling melengkapi dengan cara-cara yang unik. Namun demikian permasalahan akan timbul ketika keunikan tesebut sulit dikombinasikan dengan aset perusahaan lainnya.

5) Terlalu banyak diversifikasi

Strategi diversifikasi dapat menghasilkan daya saing strategis dan laba diatas rata-rata ketika digunakan secara benar. Secara umum, perusahaan yang menggunakan strategi diversifikasi berkaitan lebih baik daripada mereka yang menggunakan strategi diversifikasi tidak berkaitan. Namun pada suatu titik tertentu perusahaan dapat melakukan diversifikasi secara 
berlebihan. Kebutuhan perusahaan diversifikasi untuk mampu memproses informasi yang jauh lebih bervariasi menciptakan situasi yang akan menyebabkan .penurunan kinerja perusahaan.

6) Manajer terlalu fokus pada Akuisisi

Kendala ini berhubungan dengan banyaknya waktu yang dihabiskan oleh menajer dalam proses akuisisi yang sedang dilakukan yang dimulai dengan penentuan studi kelayakan peruahaan yang akan diakuisisi hingga meyiapkan negosisi untuk menetapkan harga yang wajar.

7) Penciptaan perusahaan yang telalu besar

Perlu diwaspadai bahwa penciptaan perusahaan yang terlalu besar justru akan menciptakan perusahaan yang bekerja secara ineficiency.

Merger dan akuisisi bilamana dilakukan secara terencana dengan melakukan analisis terhadap faktor-faktor kompetensi inti masing-masing perusahaan maka akan menentukan keberhasilan dari proses yang dilakukan. Hunt et al. (1987) mengakhiri penelitian mereka dengan mengidentifikasi faktor-faktor yang memberikan kontribusi kepada kesuksesan dan kegagalan akuisisi (Sudarsanam, 1999). Adapun ciri-ciri merger dan akuisisi yang berhasil antara lain yaitu (Hitt et al, 2001):

1) Perusahaan yang diakuisisi dan dimerger memiliki aktiva dan sumber daya yang komplementer terhadap bisnis inti perusahaan yang mengakuisisi ataupun merger.

2) Melakukan merger dan akuisisi secara bersahabat. Integrasi yang lebih cepat dan efektif memungkinkan dapat menekan biaya yang lebih rendah.

3) Dilakukan negosisi dengan hati-hati dan cermat. Dilakukan audit sebelum merger dan akuisisi merupakan suatu cara untuk mendukung keberhasilan proses merger dan akuisisi.

4) Perusahaan yang melakukan merger mempertahankan posisi hutang dari tingkat rendah sampai moderat.

5) Telah berpengalaman dan fleksibel serta mudah beradaptasi.

6) Konsisten terhadap riset dan pengembangan dan inovasi.

\section{KESIMPULAN}

Kompetensi inti merupakan sumber daya dan kapabilitas yang mejadi sumber keunggulan kompetitif bagi perusahaan melebihi para pesaingnya. Sebagai dasar untuk melakukan suatu tindakan kopetensi inti merupakan kumpulan aktivitas perusahaan yang dilakukan secara berbeda dibandingkan dengan perusahaan pesaing dan memiliki nilai yang unik atas barang dan jasa yang ditawarkan dalam periode yang lama. Perusahaan yang melakukan penggabungan usaha mempertimbangkan kompetensi inti masing-masing perusahaan yang mendukung menghasilkan sumber daya dan kapabilitas yang komplementer sehingga meningkatkan daya saing dibandingkan dengan para pesaingnya. Berdasarkan riset menyimpulkan bahwa kompetensi inti mengendalikan aktivitas merger dan akuisisi dalam hal ini perusahaan cenderung memilih melakukan merger dan akuisisi dengan industri yang sejenis dan penerapan tehnologi yang hampir sama. 
Peluang-peluang untuk membangun nilai melalui strategi diversifikasi, integrasi atau merger dan akuisisi banyak ditemukan dalam aktivitas-aktivitas yang berkaitan pertimbangan sumber daya, kapabilitas dan kompetensi inti masingmasing perusahaan. Merger dan akuisisi merupakan upaya melakukan sinergi diantara perusahaan yang akan melakukan penggabungan. Beberapa hal yang perlu dipertimbangkan dalam rangka upaya melakukan sinergi untuk meningkatkan kompetensi inti antara lain : 1). Setiap kompetensi inti harus menyediakan suatu keunggulan kompetitf yang relevan bagi bisnis yang direncanakan. 2). Bisnis dalam portofolio harus berkaitan dengan cara-cara yang dapat membuat kompetensi inti perusahaan menguntungkan dan 3). Kombinasi kompetensi apapun haruslah unik dan sulit untuk ditiru.

Dalam merencanakan merger dan akuisisi, agar proses merger dan akuisisi dapat berjalan dengan baik maka faktor sumber daya, kapabilitas dan kompetensi inti harus dilakukan analisis secara mendalam. Sinkronisasi terhadap kompetensi inti masing-masing perusahaan yang akan dimerger dan diakuisisi sangat berpengaruh pada tingkat keberhasilan proses merger dan akuisisi yang akan dilakukan. Kegagalan dalam menjalankan strategi merger dan akuisisi akan sangat merugikan bagi perusahaan baik perusahaan yang dimerger ataupun yang diakuisisi kuhususnya bila ditinjau dari sisi reputasi, waktu dan biaya yang telah dikeluarkan.

\section{DAFTAR PUSTAKA}

Ashford, S.J, 1988, Individual strategies for coping with stress during organizational transactions, Journal of Applied Behavioral Science, Vol 24 (1)

Brigham, Eugene F dan Joel F Houston (2001). Manajemen Keuangan. Jilid 2. Edisi 8. Edisi Bahasa Indonesia Jakarta: Erlangga

Hitt,AM, Ireland,DR \& Hoskisson, E. Robert 2001, Strategic Management : Competitiveness and Globalization, 4th Edition; Concept, Thompson Learning Asia 60 Albert Street \#15-01 Albert Complex Singapore 189969, 2001, Edisi Bahasa Indonesia Penerbit Salemba Empat Grand Wijaya Center Blok D-7 J1 Wijaya 2 Jakarta 12160.

Hussinger, Katrin, 2005, Did Concentration on Core Competencies Drive Merger and Acquisition in the 1990s?, Center for European Economic Research

Marks,M.L and Mirvis.P.H,1997, Revisiting the merger syndrome:Dealing with stress, Merger and Acquisition, Sept/Oct. 33.

Milman,C.D. 1999, Merger and acquisition activity in China: 1985 - 1996, Multinational business review

Moin, Abdul., 2003. Merger, Akuisisi dan Divestasi. Jilid 1. Yogyakarta: Ekonisia

Muhammad S, 2004, Manajemen Strategik : Konsep dan Kasus, edisi ke tiga Unit Penerbit dan Percetakan Akademi Manajemen Perusahaan YKPN.

Payamta, 2001, Analisis Pengaruh Merger dan Akuisisi terhadap perubahan kinerja perusahaan publik di Indonesia, Artikel dalam makalah SNA,Bandung 2001 . 
Pearce \& Robinson, 2007, Strategic Management : Formulation, Implementation and Control, $10^{\text {th }}$ Edition , 2007 by McGraw Hill Companies, Inc, Edisi Bahasa Indonesia, 2008 Penerbit Salemba Empat Wijaya Grand Center Blok D 7 Jl. Wijaya 2 jakarta 12160.

Schweiger,D.M, E.Csiszar and N.K. Napier (1993), Implementing International mergers and Acquisitions, Human resource planning

Sobirin, Ahmad, 2001. Merger dan akuisisi : Sebuah Perkawinan Paradoksal. Jurnal Siasat Bisnis No 6 Vol 1 tahun 2001.

Sudarsanam, P.S, 1999. The Essence of Mergers and Acquisitions. Jilid 1. Edisi 1 terjemahan Bahasa Indonesia. Yogyakarta: ANDI.

Syaiful M, Ruky , 1997, Business Valuation Suatu Pengantar, Business valuation dalam memperkirakan nilai saham dan korporat, makalah pada Workshop di Jakarta.

Very,P., Lumbatkin, M., and Calori,R. 1996, Across-national asessessment of acculturative stress in recent European mergers, International Studies of Management and Organization, Spring, 26.

www.koran-jakarta.com, 2009, diakses dan diunduh tanggal 25 Desember 2009

www.imf-x.com, 2009, diakses dan diunduh tanggal 1 Januari 2010

www.detikfinance.com, 2009 diakses dan diunduh 1 Januari 2010 